\title{
PENGARUH SIKAP, NORMA SUBJEKTIF, DAN PENDIDIKAN KEWIRAUSAHAAN TERHADAP INTENSI BERWIRAUSAHA PADA MAHASISWA
}

\author{
Ferdy Purbawijaya dan Nur Hidayah \\ Program Studi Manajemen Fakultas Ekonomi Universitas Tarumanagara, Jakarta \\ Ferdy.115170353@stu.untar.ac.id
}

\begin{abstract}
Attitude is a reaction to a situation or action that occurs around us. Subjective norms are the support of people around us to be able to determine an action to be taken. Entrepreneurship education is an individual's conscious effort to increase knowledge about entrepreneurship. This study aims to study the effect of attitudes, subjective norms, and entrepreneurship education on entrepreneurial intentions in FEB students at Tarumanagara University. The population in this study were FEB students at Tarumanagara University. Sampling in this study using purposive sampling method. Data was obtained and collected using an online questionnaire with the characteristics of being a student of FEB Tarumanagara University. The results of this study indicate that attitudes, subjective norms and entrepreneurship education have an influence on the entrepreneurial intentions of FEB Tarumanagara University students.
\end{abstract}

Keywords: attitude, Norm, Education, Entrepreneurial Intention

Abstrak: Sikap merupakan sebuah reaksi terhadap suatu keadaan maupun tindakan yang terjadi di sekililing kita. Norma subjektif merupakan dukungan dari orang disekililing kita untuk dapat menentukan suatu tindakan yang akan dilakukan. Pendidikan kewirausahaan adalah upaya sadar individu untuk meningkatkan pengetahuan tentang kewirausahaa. Penelitian ini bertujuan untuk mempelajari pengaruh dari sikap, norma subjektif, dan pendidikan kewirausahaan terhadap intensi berwirausaha pada mahasiswa FEB Universitas Tarumanagara. Populasi dalam penelitian ini adalah mahasiswa FEB Universitas Tarumanagara. Pengambilan sampel pada penelitian ini menggunakan metode purposive sampling. Data diperoleh dan dikumpulkan dengan mengunakan kuisioner online dengan karakteristik yang merupakan Mahasiswa FEB Universitas Tarumanagara. Hasil penelitian ini menunjukan bahwa Sikap, Norma subjektif dan pendidikan kewirausahaan memiliki pengaruh terhadap intensi berwirausaha Mahasiswa FEB Universitas Tarumanagara.

Kata Kunci: Sikap, Norma, Pendidikan, Intensi Berwirausaha

\section{LATAR BELAKANG}

Saat ini Indonesia masih mengalami masalah pengangguran karena banyaknya angkatan kerja tidak sebanding dengan jumlah lapangan pekerjaan yang tersedia. Salah satu cara untuk 
mengatasi pengangguran dan meningkatkan perekonomian Indonesia adalah dengan meningkatkan minat berwirausaha generasi muda khususnya mahasiswa perguruan tinggi. Wirausaha adalah sebuah kegiatan usaha atau suatu bisnis mandiri yang setiap sumber daya dan kegiatannya dibebankan kepada pelaku usaha atau wirausahawan terutama dalam hal membuat produk baru. Wirausahawan didefinisikan sebagai individu yang memiliki intensi untuk mencapai peluang tertentu, memasuki pasar baru, dan menawarkan produk baru (Slamet dkk., 2014). Data menunjukan bahwa jumlah wirausahawan yang ada di Indonesia hanya mencapai kurang dari 3\% dari jumlah penduduk di Indonesia (okezone.com, 2020).

Hal ini dapat dibuktikan dari hasil KBRN, Pekanbaru yang dimana jumlah wirausahawan hanya sekitar 8.06 juta jiwa dibandingkan dengan jumlah 260 juta penduduk Indonesia saat ini. Jumlah ini masih kalah jika dibandingkan dengan beberapa negara di Asia Tenggara, dimana skor yang diperoleh Indonesia sebesar 0,7 dari skala 10 menurut laporan dari US News dan World Report dalam 2019 Best Countries. peringkat kewirausahaan Indonesia di ASEAN mendapat peringkat nomor dua terendah di ASEAN dimana peringkatnya lebih rendah dari negara Vietnam, Thailand, Malaysia dan Singapura.

Salah satu penyebab dari rendahnya kewirausahaan di Indonesia adalah sistem pendidikan yang kurang memberikan edukasi mengenai wirausaha kepada mahasiswanya sehingga tidak menumbuhkan jiwa entrepreneurship. Dapat dilihat bahwa Sebagian besar mahasiswa yang telah lulus memilih untuk menjadi karyawan dibandingkan melakukan kegiatan berwirausaha serta membuka adanya lapangan pekerjaan baru. Penting untuk Lembaga pendidikan untuk lebih menekankan pendidikan kewirausahaan yang merupakan faktor penting untuk menumbuhkan jiwa kewirausahaan sehingga mendorong terciptanya kewirausahaan yang baik, sehingga universitas memiliki peran penting untuk mendorong terciptanya intensi kewirausahaan bagi para mahasiswa.

Sikap adalah kebiasaan seseorang dalam hal memberikan respon atau mendapat rangsangan terhadap objek baik dalam rasa suka maupun tidak suka (Andika dan Madjid, 2012, h. 192). Sikap dapat disebut sebagai suatu bentok respon evaluatif terhadap suatu individu. Oleh karena itu, sikap merupakan salah satu hal yang dibutukan oleh mahasiswa agar dapat menciptakan suatu peluang usaha yang baru. Selain sikap, hal yang diperlukan untuk mendukung adanya niat dalam berwirausaha adalah norma subjektif. Norma subjektif merupakan bagaimana seseorang merasakan tekanan oleh lingkungan sekitarnya yang ditempatkan padanya untuk melakukan atau tidak melakukan tindakan tersebut. Pendidikan kewirausahaan merupakan upaya sadar individu untuk meningkatkan pengetahuan dan intensi yang memiliki inovasi, kreativitas dan berani mengambil resiko, sehingga pendidikan kewirausahaan diperlukan untuk meningkatkan intensi berwirausaha.

Berdasarkan beberapa penelitian sebelumnya, hasil yang diperoleh bahwa sikap, norma subjektif dan pendidikan kewirausahaan memiliki pengaruh yang positif namun tidak signifikan terhadap intensi berwirausaha, seperti dalam penelitian Andika dan Madjid (2012), hasil yang diperoleh bahwa norma subjektif tidak memiliki pengaruh yang signifikan terhadap intensi berwirausaha pada mahasiswa Syiah Kuala.

Berdasarkan penjelasan di atas, maka masih diperlukan adanya penelitian terkait intensi berwirausaha dengan menggunakan responden yang berbeda. Penelitian ini memiliki tujuan untuk mengetahui pengaruh sikap, norma subjektif dan pendidikan kewirausahaan terhadap intensi berwirausaha pada mahasiswa FEB Universitas Tarumanagara. 


\section{KAJIAN TEORI}

Teori yang dipakai dalam penelitian ini adalah Theory of planned Behavior yang diteliti oleh Ajzen tahun 1991. "a central factor in the theory of planned behavior is the individual's intention to perform a given behaviour" (Ajzen, 1991). Dalam pernyataan ini Ajzen mengatakan bahwa perilaku yang dilakukan oleh seseorang berawal dari niat yang dimiliki oleh orang tersebut. "Intension are assumed to capture the motivational factors that influence a behavior" (Ajzen, 1991). Yang berarti bahwa faktor yang paling penting dalam teori TPB ini adalah niat. Dapat diasumsikan bahwa niat menangkap faktor - faktor motivasi yang berpengaruh terhadap perilaku.

Intensi berwirausaha adalah kecenderungan seseorang untuk memulai sebuah bisnis baru (Akhtar dkk., 2011). Intensi berwirausaha adalah kemampuan untuk memberanikan diri dalam memenuhi kebutuhan hidup serta memecahkan permasalah hidup, memajukan atau menciptakan usaha baru dengan kekuatan yang ada pada diri sendiri (Yanto, 1996). Intensi Berwirausaha adalah suatu pikiran yang mendorong individu menciptakan usaha (Adnyana dan Purnami, 2016). Berdasarkan definisi menurut para ahli, dapat disimpulkan bahwa intensi berwirausaha merupakan suatu pikiran yang mendorong keinginan seseorang utuk menciptakan suatu usaha dengan kemampuan yang dimiliki oleh suatu individu.

Sikap adalah A learned predisposition to respond in a constistenly favourable or unfavorable manner with respect to a given object (Fishbein dan Ajzen, 1975). Dapat disimpulkan dari definisi di atas, sikap dapat diartikan sebagai kecenderungan yang dimiliki oleh suatu individu terhadap suatu objek, dimana kecenderungan itu dapat membentuk respon yang menguntungkan atau tidak menguntungkan. Terdapat keterkaitan antara sikap dengan intensi berwirausaha. Dalam teori TPB oleh Ajzen (1991) dikatakan bahwa ada tiga faktor penentu yang mempengaruhi niat secara konseptual, salah satunya adalah sikap.

Norma Subjektif adalah persepsi individu tentang apakah orang lain akan mendukung atau tidak terwujudnya tindakan tersebut (Caecilia, 2012). Dapat disimpulkan bahwa norma subjektif adalah persepsi atau pandangan terhadap seseorang atau lingkungan yang dapat mempengaruhi tindakan dari seorang individu. Terdapat keterkaitan antara norma subjektif dengan intensi berwirausaha. Dalam teori TPB oleh Ajzen (1991) dikatakan bahwa ada tiga faktor penentu yang mempengaruhi niat secara konseptual salah satunya adalah norma subjektif.

Pendidikan kewirausahaan adalah disiplin ilmu yang mempelajari nilai, keterampilan dan perilaku dalam menghadapi tantangan hidup untuk mengejar peluang dengan berbagai macam resiko yang mungkin di hadapi (Kurniawan, 2013). Dapat disimpulkan bahwa pendidikan kewirausahaan merupakan pendidikan yang memberikan ilmu tentang kecakapan hidup sehingga memiliki keterampilan untuk membuka sebuah peluang kewirausahaan. Terdapat keterkaitakan antara pendidikan kewirausahaan dengan intensi berwirausaha. Pendidikan kewirausahaan dikatakan dapat meningkatkan semangat serta mengembangkan pengetahuan dan keterampilan berwirausaha sehingga dapat meningkan intensi berwirausaha.

Sikap, norma subjektif dan pendidikan kewirausahaan berpengaruh pada intensi berwirausaha pada mahasiswa Fakultas Ekonomi dan Bisnis Universitas Tarumanagara dapat digambarkan sebagai berikut: 


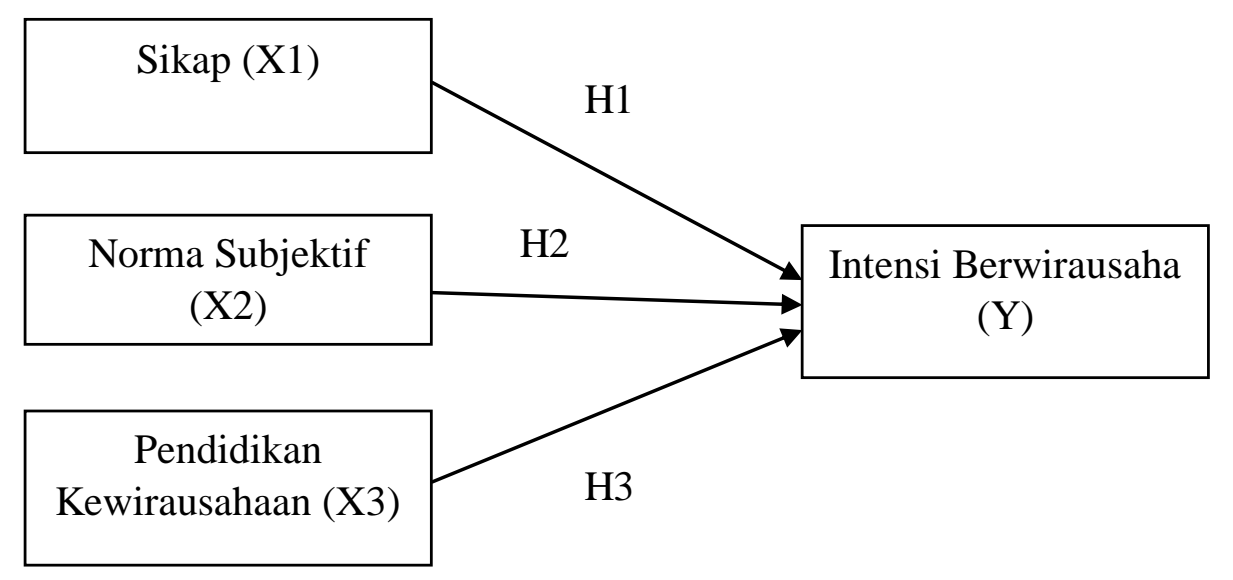

Gambar 1. Model Penelitian

Hipotesis yang digunakan dalam penelitian ini adalah sebagai berikut:

H1: Sikap memiliki pengaruh positif terhadap intensi berwirausaha pada mahasiswa FEB Universitas Tarumanagara.

H2: Norma Subjektif memiliki pengaruh positif terhadap intensi berwirausaha mahasiswa FEB Universitas Tarumanagara.

H3: Pendidikan kewirausahaan memiliki pengaruh positif terhadap intensi berwirausaha pada mahasiswa FEB Universitas Tarumanagara.

\section{METODOLOGI}

Metode penelitian ini pada umumnya merupakan cara ilmiah untuk memperoleh data dengan tujuan dan manfaat tertentu (Sugiyono, 2012). Metode penelitian dibagi menjadi dua jenis yaitu metode kualitatif dan kuantitatif. Penelitian ini menggunakan metode kuantitatif dengan desain penelitian deskriptif, dengan tujuan untuk memecahkan masalah yang akan diteliti dengan memproyeksikan suatu keadaan subjek maupun objek dalam sebuah penelitian. Metode deskriptif adalah suatu metode dalam meneliti status kelompok manusia, suatu objek, suatu set kondisi, suatu sistem pemikiran ataupun suatu kelas peristiwa pada masa sekarang (Nazir, 1983). Desain penelitian ini akan digunakan untuk menguji pengaruh variable sikap, norma subjektif dan pendidikan kewirausahaan terhadap intensi kewirausahaan. Dengan menggunakan metode pengumpulan data menggunakan kuisioner atau angket.

Populasi adalah Keseluruhan unsur yang menjadi subjek penelitian disebut populasi atau biasanya disebut juga universe (Aritonang, 2007). sampel adalah bagian dari jumlah dan karakteristik yang dimiliki oleh populasi tersebut (Sugiyono, 2012). Metode pemilihan sampel terdiri dari probability sampling dan non-probability sampling. Penelitian ini menggunakan nonprobability sampling dengan Teknik pengambilan sampel purposive sampling, dalam penelitian ini menetapkan kriteria secara khusus yang sesuai dengan tujuan penelitian sehingga dapat menjawab permasalahan penelitian yang akan di teliti. Sampel yang digunakan dalam penelitian 
ini ada mahasiswa Universiteras Tarumanagara dengan kriteria khusus yaitu mahsiswa Fakultas Ekonomi dan Bisnis yang masih aktif kuliah.

Penelitian ini menggunakan kuisioner melalui google form. Peneliti menyebarkan kuisoner kepada subjek penelitian yaitu mahasiswa dan mahasiswi FEB Universitas Tarumanagara. Jumlah responden yang digunakan dalam penelitian ini sebanyak 61 responden. Ada beberapa karakteristik yang digunakan dalam penelitian ini. Karakteristik pertama adalah jenis kelamin mahasiswa FEB Universitas Tarumanagara yang terdiri dari 36 responden berjenis kelamin lakilaki (59\%) dan 25 responden berjenis kelamin perempuan (41\%). Karakteristik kedua, yaitu jurusan. Sebanyak 61 responden merupakan mahasiswa jurusan manajemen (100\%) dan sebanyak 0 responden merupakan mahasiswa akuntansi $(0 \%)$. Karakteristik ketiga, yaitu semester. Sebanyak 0 responden merupakan mahasiswa semester 1-4 (0\%), sebanyak 51 responden merupakan mahasiswa semester 5-8 $(83,6 \%)$ dan sebanyak 10 responden merupakan mahasiswa semester 8> $(16,3 \%)$.

Tingkat validitas dapat terlihat dari hasil pengujian validitas konvergen dan validitas diskriminan. Validitas konvergen berhubungan dengan prinsip bahwa pengukur-pengukur dari suatu konstruk seharusnya berkorelasi tinggi, Validitas konvergen terjadi jika skor yang diperoleh dari dua instrument yang berbeda mengukur konstruk yang sama mempunyai korelasi tinggi (Hartono, 2008). Validitas konvergen dalam penelitian ini adalah dengan mengukur nilai Average Variance Extracted (AVE) dan Outer Loadings factor. Nilai pada Average Variance Extracted (AVE) yang harus diperoleh minimal 0,5. jika nilai AVE kurang dari 0,5, maka dinyatakan tidak valik. Untuk nilai outer loading antara 0,4 sampai 0,7 termasuk kategori outer loading yang lemah dan diperhitungkan untuk dihapus jika memang dengan dihapusnya indikator tersebut dapat meningkatkan hasil perhitungan (Hair, hult, Ringle \& Sarstedt, 2017). Data yang memiliki nilai outer loading $<0,7$ harus dihapus dalam penelitian ini karerna data tersebut tidak dinyatakan valid dalam penelitian ini. Nilai outer Loading untuk variabel sikap $(\mathrm{S} 1=0,752, \mathrm{~S} 2=0,742, \mathrm{~S} 3=0,803$, $\mathrm{S} 4=0,755)$, variabel norma subjektif $(\mathrm{NS} 3=0,759$, $\mathrm{NS} 4=0,937)$, variabel pendidikan kewirausahaan $(\mathrm{PK} 1=0,813, \mathrm{PK} 2=0,819, \mathrm{PK} 3=0,733)$, variabel intensi berwirausaha $(\mathrm{IB} 1=0,880$, IB2 $=0,811$, IB3 $=0,807$, IB4=0,785, IB5=0,703). Nilai dari outer loading dari keempat variabel dinyatakan valid karena memiliki nilai lebih besar dari 0,7 .

Uji reliabilitas adalah sebuah alat ukur untuk menguji suatu indikator dari sebuah kuisioner dan bertujuan untuk menjelaskan bahwa data tersebut dapat dipercaya. Uji realibilitas mengacu pada sejauh mana skala yang memberikan hasil konsisten pada pengukuran data yang dilakukan secara berulang-ulang (Malhotra, 2010). Penelitian ini menggunakan Composite Realibilty (CR) dan Cronbach's Alpha. data akan dinyatakan Reliable jika CR > 0,7 dan data dinyatakan tidak reliable jika CR < 0,7. Nilai koefisien Cronbach's Alpha dinyatakan reliable jika nilai lebih besar dari 0,6 sedangkan jika nilai kurang dari 0,6 maka dinyatakan tidak reliabel (Sujarweni, 2014).

Di mana variabel sikap memperoleh nilai $(\mathrm{AVE}=0.582, \mathrm{CA}=0.762, \mathrm{CR}=0.848)$, variabel norma subjektif memperoleh nilai $(\mathrm{AVE}=0.728, \mathrm{CA}=0.653, \mathrm{CR}=0.841)$, variabel pendidikan kewirausahaan $(\mathrm{AVE}=0.623, \mathrm{CA}=0.703, \mathrm{CR}=0.832)$, variabel intensi berwirausaha $(\mathrm{AVE}=$ $0.639, \mathrm{CA}=0.858, \mathrm{CR}=0.898)$. sehingga keempat variabel dinyatakan valid dan reliabel.

\section{HASIL ANALISIS DATA}


Tujuan dari uji ini adalah untuk menentukan sejauh mana tingkat keterkaitan antara variabel dependen dengan variabel independen. Nilai R-square juga digunakan umtuk menghitung besarnya peranan atau pengaruh variabel bebas pada variabel tergantung. Koefisien determinasi dihitung dengan cara mengalikan $\mathrm{R}^{2}$ dengan $100 \%$ (Sarwono dan Budiono, 2012). Hasil output dari SmartPLS 3.0 memperoleh nilai $\mathrm{R}^{2}$ sebesar 0,634. Uji ini dilakukan untuk melihat pengaruh antara variabel dependen dengan variabel independen yang ada dalam penelitian ini yaitu sebesar $63,4 \%$ terhadap 3 variabel independen yaitu sikap, norma subjektif dan pendidkan kewirausahaan. Sedangkan sebesar 36,6\% dipengaruhi oleh variabel independen lain yang tidak digunakan di dalam penelitian ini.

Pengujian ini diperlukan untuk memvalidasi suatu model. Hasil $\mathrm{Q}^{2}$ dikatakan baik jika nilainya $>0$ menunjukan bahwa variabel laten eksogen mempunyai predictive Relevance pada variabel endogennya sebaliknya, jika nilainya $<0$ maka hasil tersebut kurang memiliki predictive relevance. Nilai $\mathrm{Q}^{2}$ yang diperoleh sebesar 0,340 di mana nilai tersebut lebih besar dari 0 . Hal ini menunjukan bahwa sikap, norma subjektif, dan pendidikan kewirausahaan memiliki kontribusi yang baik terhadap intensi berwirausaha.

Hasil uji Effect Size $\left(F^{2}\right)$, sikap memperoleh nilai sebesar 0.595 sehingga dapat dikatakan sikap memiliki pengaruh yang besar terhadap intensi berwirausaha, selanjutnya nilai dari norma subjektif dan pendidikan kewirausahaan memiliki nilai sebesar 0,022 dan 0,108 sehingga norma subjektif dan pendidikan kewirausahaan memiliki pengaruh yang kecil terhadap intensi berwirausaha.

Goodness of Fit (GOF) diperlukan untuk memvalidasi model struktural secara keseluruhan. Nilai GOF terdiri di antara 0 sd 1 dengan interprestasi nilai sebagai berikut : 0.1 (GOF kecil), 0.25 (GOF moderat) dan 0.36 (GOF besar). Nilai GOF mempengaruhi diterima atau tidak diterimanya model tersebut. Jika nilainya baik maka model tersebut akan diterima, sebaliknya jika nilainya buruk maka model tersebut tidak dapat diterima. Hasil Goodness of Fit pada penelitian ini memiliki nilai sebesar 0,638 , yang berarti model struktural yang digunakan memiliki tingkat kecocokan sebesar 63,8\%.

Hasil dari pengujian path coefficient penelitian ini adalah sikap $(+0,570)$, Norma Subjektif $(+0,119)$ dan pendidikan kewirausahaan $(+0,247)$ memiliki hubungan yang positif terhadap intensi berwirausaha.

\section{Tabel 1}

Hasil Pengujian Hipotesis

\begin{tabular}{|l|c|c|c|c|c|}
\hline & $\begin{array}{c}\text { Original } \\
\text { Sample (O) }\end{array}$ & $\begin{array}{c}\text { Sample Mean } \\
(\mathbf{M})\end{array}$ & $\begin{array}{c}\text { Standar } \\
\text { Deviation } \\
\text { (STDEV) }\end{array}$ & $\begin{array}{c}\text { T Statistics } \\
(\mid \mathbf{O} / \text { STDEV })\end{array}$ & P Values \\
\hline (S)->(IB) & 0.570 & 0.574 & 0.106 & 5.360 & 0.000 \\
\hline (NS)->(IB) & 0.119 & 0.108 & 0.102 & 1.168 & 0.243 \\
\hline (PK)->(IB) & 0.247 & 0.262 & 0.097 & 2.537 & 0.011 \\
\hline
\end{tabular}

Hipotesis pertama, path coefficient sebesar 0,570 menunjukan besarnya pengaruh sikap terhadap intensi berwirausaha. Hasil nilai t-statistics adalah 5,360 yang berarti lebih tinggi dari batas 
minimum 1,96. Hasil nilai $p$-value adalah 0,000 yang berarti lebih rendah dari level of significance (nilai signifikan) 0,05. Berdasarkan hasil tersebut, dapat dinyatakan bahwa hipotesis pertama di terima. Kesimpulan yang dapat diambil adalah sikap memiliki pengaruh positif dan signifikan terhadap intensi berwirausaha pada mahasiswa FEB Universitas Tarumanagara.

Hipotesis kedua, path coefficient sebesar 0,119 menunjukan besarnya pengaruh norma subjektif terhadap intensi berwirausaha. Hasil nilai $t$-statistics adalah 1,168 yang berarti lebih rendah dari batas minimum 1,96. Hasil nilai $p$-value adalah 0,243 yang berarti lebih tinggi dari level of significance (nilai signifikan) 0,05. Berdasarkan hasil tersebut, dapat dinyatakan bahwa hipotesis kedua ditolak. Kesimpulan yang dapat diambil adalah norma subjektif memiliki pengaruh positif tetapi tidak signifikan terhadap intensi berwirausaha pada mahasiswa FEB Universitas Tarumanagara.

Hipotesis ketiga, path coefficient sebesar 0,247 menunjukan besarnya pengaruh pendidikan kewirausahaan terhadap intensi berwirausaha. Hasil nilai $t$-statistics adalah 2,537 yang berarti lebih tinggi dari batas minimum 1,96. Hasil nilai $p$-value adalah 0,011 yang berarti lebih rendah dari level of significance (nilai signifikan) 0,05. Berdasarkan hasil tersebut, dapat dinyatakan bahwa hipotesis ketiga diterima. Kesimpulan yang dapat diambil adalah pendidikan kewirausahaan memiliki pengaruh positif dan signifikan terhadap intensi berwirausaha pada mahasiswa FEB Universitas Tarumanagara.

\section{DISKUSI}

Hipotesis Pertama: Sikap memiliki pengaruh positif dan signifikan terhadap intensi berwirausaha pada mahasiswa FEB Universitas Tarumanagara. Hasil tersebut sesuai dengan penelitian sebelumnya yang berjudul "Attitude, Subjective Norms, Perceived Behaviour, Entrepreneurship Education and Self-efficacy Toward Entrepreneurial Intention University Student in Indonesia" (Utami, 2017). bahwa sikap memiliki pengaruh signifikan terhadap intensi berwirausaha. Hasil tersebut juga sejalan dengan penelitian Eric J. Schwarz, et all (2009) dan penelitian Tjahyono \& Ardi (2008) yang menunjukan bahwa sikap yang positif terhadap kewirausahaan meningkatkan niat berwirausaha siswa untuk menjadi wirausaha. Pada penelitian ini, mahasiswa FEB Universitas Tarumanagara memiliki sikap yang diperlukan untuk meningkatkan intensi berwirausahanya yaitu sikap untuk memiliki usaha sendiri dibandingkan memiliki perkerjaan aman, sikap untuk memanfaatkan peluang bisnis baru yang ada dan memiliki pandangan positif terhadap kegagalan bisnis yang dialami, sehingga dengan adanya sikap tersebut maka akan mempengaruhi intensi berwirausaha dari para mahasiswa FEB Universitas Tarumanagara. Sikap menjadi salah satu variabel yang berpengaruh dalam meningkatkan intensi berwirausaha. Para mahasiswa harus bisa memanfaatkan setiap peluang bisnis dan pengalaman yang ada. Pemanfaatan peluang bisnis dan pengalaman yang ada maka para mahasiswa dapat keluar dari zona nyaman mereka sehingga akan lebih peka terhadap ide bisnis baru yang lebih unik dan menarik sehingga dapat menciptakan suatu usaha sendiri daripada hanya memiliki pekerjaan aman yaitu berkerja dengan orang lain.

Hipotesis Kedua: Norma subjektif memiliki pengaruh positif tetapi tidak signifikan terhadap intensi berwirausaha mahasiswa FEB Universitas Tarumanagara. Hasil penelitian ini sejalan dengan hasil penelitian sebelumnya yang berjudul "Analisis Pengaruh Sikap, Norma Subyektif dan Efikasi Diri terhadap Intensi Berwirausaha pada Mahasiswa Ekonomi Universitas 
Syiah Kuala" (Andika \& Madjid, 2012), pada penelitian tersebut variabel norma subjektif tidak memiliki pengaruh yang signifikan terhadap intensi berwirausaha, hasil ini dapat dilihat dari tingkat signifikasinya yaitu sebesar 0,393 dimana nilainya lebih besar dari 0,05. Hasil penelitian ini tidak sejalan dengan penelitian sebelumnya yang berjudul "Attitude, Subjective Norms, Perceived Behaviour, Entrepreneurship Education and Self-efficacy Toward Entrepreneurial Intention University Student in Indonesia" (Utami, 2017). pada penelitian tersebut norma subjektif memiliki pengaruh yang signifikan terhadap intensi berwirausaha. Hasil penelitian ini juga tidak sejalan dengan penelitian Garcia dan Moreno (2010) pada penelitian tersebut norma subjektif memiliki pengaruh yang positif dan signifikan terhadap intensi berwirausaha. Pada penelitian ini, mahasiswa FEB Universitas Tarumanagara kurang memiliki norma subjektif yang dapat meningkatkan intensi berwirausaha, dikarenakan terdapat responden yang kurang mendapatkan dukungan dalam berwirausaha dari pihak keluarga. Hal ini dapat terjadi dikarenakan mayoritas keluarga dari responden sendiri memilih untuk berkeja dengan orang lain sehingga menciptakan persepsi pada diri responden untuk memilih bekerja dengan orang lain juga dibandingkan dengan membuka usaha sendiri. Padahal keluarga memiliki peran penting pada diri seorang individu untuk mengarahkan pada kecenderungan dalam berwirausaha (Marini dan Hamidah, 2014). Kurangnya dukungan dari orang yang di anggap penting seperti teman dan pengusaha sukses juga mempengaruhi persepsi seseorang untuk menumbuhkan intensi berwirausaha pada diri seseorang.

Hipotesis Ketiga: Pendidikan kewirausahaan memiliki pengaruh positif dan signifikan terhadap intensi berwirausaha mahasiswa FEB Universitas Tarumanagara. Hasil tersebut sejalan dengan penelitian sebelumnya yang berjudul "Attitude, Subjective Norms, Perceived Behaviour, Entrepreneurship Education and Self-efficacy Toward Entrepreneurial Intention University Student in Indonesia" (Utami, 2017), pada penelitian tersebut, pendidikan kewirausahaan memiliki pengaruh yang signifikan terhadap intensi berwirausaha. Hasil ini juga t sejalan dengan penelitian Nur Santi, dkk (2017) dan penelitian Supriyanto \& Meilita (2017) dimana dalam penelitian tersebut, pendidikan kewirausahaan memiliki pengaruh yang positif dan signifikan terhadap intensi berwirausaha mahasiswa. Pada penelitian ini, mahasiswa FEB Universitas Tarumanagara memperoleh pendidikan kewirausahaan yang cukup sehingga dapat meningkatkan pengetahuan kewirausahaan dan memupuk program untuk menumbuhkan kesadaran peluang bisnis sehingga dapat meningkatkan intensi berwirausaha. Para mahasiswa harus memanfaatkan pendidikan kewirausahaannya sehingga dapat meningkatkan keinginan dan menginsipirasi untuk mengambil sebuah tantangan baru yaitu membuka usaha sendiri.

\section{PENUTUP}

Ada beberapa saran yang dapat diberikan berdasarkan hasil dari penelitian ini, antara lain. Bagi peneliti selanjutnya disarankan untuk menggunakan responden yang lebih banyak dari penelitian ini serta bisa diambil dari responden yang mengarah kepada konsentrasi kewirausahaan. Penelitian selanjutnya juga disarankan untuk menggunakan variabel independen lain yang mempengaruhi intensi berwirausaha seperti variabel efikasi diri, kontrol perilaku dan variabel lainnya. Sedangkan saran bagi praktisi yaitu dalam pembelajaran saat ini terkait merdeka belajar kampus merdeka maka diharapkan mahasiswa bisa memanfaatkan semaksimal mungkin dengan mengikuti magang pada tempat-tempat usaha yang bisa memberikan ilmu yang dapat bermanfaat sebagai bekal berwirausaha. Selain itu juga bisa mengikuti kuliah pada Fakultas lain yang ada di 
Universtas Tarumanagara atau mengikuti kuliah pada Fakultas Ekonomi dan Bisnis di Universitas lain dalam atau luar Negeri dengan mengambil mata kuliah yang bermanfaat untuk dapat meningkatkan kemampuan dalam berwirausaha. Terkait norma subjektif pada mahasiswa maka perlu ditingkatkan adanya dukungan yang lebih kuat dari keluarga, teman, dosen dan orang yang dianggap memiliki peran penting dalam meningkatkan intensi berwirausaha.

\section{DAFTAR PUSTAKA}

Aritonang, R. L. R. (2007). Riset pemasaran: teori \& praktik. Bogor: Ghalia Indonesia.

Alfianto, E. A. (2012). Kewirausahaan: sebuah kajian pengabdian kepada masyarakat. Jurnal Heritage, 1(2), $34-42$.

Ajzen, I. (1991). The Theory of Planned Behavior, Organizational Behavior and Human Decision Processes, vol. 50, no. 2, pp. 179-211

. (1991). The Theory of Planned Behavior. Organizational Behavior and Human Decision Process. Amherst, MA: Elsevier, 50, 179-211.

Andhika, M., \& Madjid, I. (2012). Analisis pengaruh sikap, norma subjektif dan efikasi diri terhadap intensi berwirausaha pada mahasiswa Fakultas Ekonomi Universitas Syiah Kuala. In eco entrepreneurship seminar \& call for paper" improving performance by inproving encviroment. 190-196

Akhtar Ali, Keith J. Topping \& Riaz H. Tariq. (2011). Entrepreneurial Attitudes among Potential Entrepreneurs. International journal Pak. J. Commer. Soc. Sci. 5(1): h: 12-46

Adnyana, Purnami. (2016). Pengaruh Pendidikan Kewirausahaan, Self-Efficacy Dan Locus Of Control Pada Niat Berwirausaha. E-Jurnal Manajemen Unud, Vol. 5, No. 2, 2016: 11601188 ISSN: 2302-8912

Caecilia Vemmy,S. (2012). Faktor-Faktor yang Mempengaruhi Intensi Berwirausaha Siswa SMK. Jurnal Pendidikan Vokasi. 2 (1): h: 117-126

Díaz-García, M. and Jiménez-Moreno, J. (2010), "Entrepreneurial intention: the role of gender",International Entrepreneurship and Management Journal, Vol. 6 No. 3, pp. 261283,doi: 10.1007/s11365-008-0103-2.

Fishbein, M, \& Ajzen, I. (1975). Belief, Attitude, Intention, and Behavior: An Introduction to Theory and Research, Reading, MA: Addison-Wesley.

Hair, J., Hult, G., Ringle, C., \& Sarstedt, M. (2017). A Primer on Partial Least Squares Structural Equation Modeling (PLS-SEM) (2 nd ed.). Thousand Oaks: SAGE.

Rahmat Kurniawan. (2013). Pengaruh Penerapan Model Pembelajaran Teaching Factory 6 Langkah (Tf-6m) dan Prestasi Belajar Kewirausahaan Terhadap Minat Wirausaha . INVOTEC, Volume X, No.1, Februari 2014 : 57- 66 Program Studi Pendidikan Teknologi dan Kejuruan Sekolah Pasca Sarjana Universitas Pendidikan Indonesia

Marini, C. K, \& Hamida, S. (2014). Pengaruh self-efficacy, lingkungan keluarga, dan lingkungan sekolah terhadap minat berwirausaha siswa SMK Jasa Boga. Jurnal Pendidikan Vokasi, 4(2), $195 \pm 207$.

Malhotra, N. K. (2010). Marketing Research: An Applied Orientation (6th ed.). Upper Saddle River, New Jersey: Pearson Education.

Slamet, F., Tunjungsari, H., K., \& Mei, I. (2014). Dasar-Dasar Kewirausahaan, Teori dan Praktik, Jakarta: Indeks. 
Supriyanto, \& Meilita, E. (2017). Pengaruh Pendidikan Kewirausahaan Terhadap Intensi Berwirausaha. Jurnal Ilmu Administrasi, 9(2), 50-63

Sugiyono. (2012). Metode Penelitian Pendidikan Pendekatan Kuantitatif, Kualitatif dan R \& D. Bandung: Alfabeta.

Schwarz, E. J., Wdowiak, M. A., Almer-Jarz, D. A., \& Breitenecker, R. J. (2009). The effects of attitudes and perceived environment conditions on students' entrepreneurial intent: An Austrian perspective. Education and Training, 51(4), 272-291. https://doi.org/10.1108/00400910910964566

Sarwono, Jonathan dan Budiono, Herlina. (2012). Statistika Terapan: Aplikasi (Untuk Riset Skripsi, Tesis dan Disertasi Menggunakan SPSS, AMOS dan Excel). Jakarta: PT Elex Media Komputindo.

Santi, Nur., Haamzah, Amir., \& Teti Rahmawati. (2017). "Pengaruh Efikasi Diri, Norma Subjektif, Sikap Berperilaku dan Pendidikan Kewirausahaan terhadap Intensi Berwirausaha". Jurnal Inspirasi Bisnis dan Manajemen, 1(1): 63-74.

Sujarweni, V. W. (2014). SPSS untuk Penelitian. Yogyakarta: Pustaka Baru Press.

Tjahjono, H.K dan Ardi H. (2008). Kajian Niat Mahasiswa Manajemen Universitas Muhammadiyah Yogyakarta Untuk Menjadi Wirausaha. Jurnal Manajemen dan Bisnis Vol. 16 No.1

Utami, C. W. (2017). Attitude, Subjective Norms, Perceived behavior, Entrepreneurship education and Self-efficacy toward entrepreneurial intention University student in Indonesia. European Research Studies Journal, 20(2), 475-495.

Yanto. (1996). Peluang Kerja dan Minat Berwiraswasta di Kalangan Siswa Sekolah Teknologi Menengah Negeri Pembangunan Pekalongan. Semarang: IKIP Semarang. 